\title{
Accountability of Law Enforcement Personnel for Human Rights Violations in Cameroon: Trends and Challenges
}

\section{P.E.R}

Pioneer in peer-reviewed, open access online law publications

\section{Author}

Avitus A Agbor

\section{Affiliation}

North-West University

South Africa

\section{Email Avitus.Agbor@nwu.ac.za}

Date Submission

\section{March 2021}

Date Revised

\section{September 2021}

\section{Date Accepted}

1 September 2021

Date published

\section{October 2021}

\section{Editor Mr M Laubscher}

\section{How to cite this article}

Agbor AA "Accountability of Law Enforcement Personnel for Human Rights Violations in Cameroon: Trends and Challenges" PER / PELJ 2021(24) - DOI http://dx.doi.org/10.17159/1727$3781 / 2021 / v 24 i 0 a 10395$

\section{Copyright}

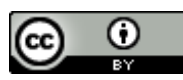

DOI

http://dx.doi.org/10.17159/17273781/2021/v24i0a10395

\begin{abstract}
Law enforcement personnel are critically important in both the security and criminal justice sectors. Unlike ordinary citizens, they possess the broad powers needed to perform the tasks in these sectors: for example, they possess the power to arrest and detain; to search premises and seize items; to interrogate individuals; to stop assemblies; to check and even to restrict the movements of people during certain times; and to use force and firearms in specific circumstances. In exercising such powers, they are required to act independently and judiciously. Also, they must stay within the remit of the law. Such powers, however, render them prone to committing human rights abuses since by their very nature, they interfere with the civil and political rights of individuals. In instances of violations, they are expected to be held accountable. Accountability for law enforcement for human rights violations evokes and entails the notions of lawfulness and legitimacy. As legitimacy touches on the public perception of law enforcement personnel, it becomes vital to explore what mechanisms are put in place to ensure accountability as well as possible challenges that hamper it. Examining the notion of the accountability of law enforcement personnel in the context of Cameroon, this paper argues that selective accountability has been the trend which puts the country at quite a distance from its international human rights obligations. Informed by empirical evidence from credible governmental bodies, the paper identifies and assesses the legal framework on accountability, touching on a few instances of selective accountability, and argues that if lawfulness and legitimacy are to be the cornerstones of accountability, then a comprehensive approach must be considered, including the de-politicisation of law enforcement units in Cameroon.
\end{abstract}

\section{Keywords}

Law enforcement personnel; accountability for human rights violations; torture in Cameroon; protection of human rights in Cameroon. 


\section{Introduction}

Annual Reports on human rights in Cameroon are prepared and published by the Ministry of Justice (MINJUST). ${ }^{1}$ These Annual Reports detail pertinent aspects relating to the respect for, promotion and protection of human rights in Cameroon. Human rights violations committed by law enforcement personnel in Cameroon have featured regularly therein and a snapshot of these violations is provided below. The perpetration of (such) human rights violations by law enforcement personnel (agents of the state) touches on a number of key issues: the place of human rights in the legal system; the democratic culture of a state; and the accountability measures that are in place to ensure that such violations are investigated and the perpetrators thereof held accountable.

Law enforcement personnel occupy a unique place in a legal system. They are given numerous powers in the security and criminal justice sectors. ${ }^{2}$ These include the powers to arrest and detain; to search a place and seize any item that was involved in a crime; to identify and interrogate any suspect and witness; to subject individuals to specific tests like sobriety tests; to dispel an assembly and contain rioters; to prohibit entry into premises; to control the movements of people; and to use physical force when necessary. ${ }^{3}$ Obviously, these are broad powers which are monopolised by law enforcement personnel. These powers make law enforcement personnel prone to go beyond established legal limits. The excessive exercise of these powers often results in abuses and constitutes misconduct. In addition, it may interfere with the rights of individuals. As such, the need to regulate the conduct of law enforcement personnel is important and has a direct bearing on the respect for, promotion of and protection of human rights. ${ }^{4}$ For example, they may violate someone's right to life when unnecessary and disproportionate lethal force is used against an individual. They may restrict the free movement of persons and conduct

Avitus A Agbor. LLB (Hons) (Buea) LLM (Notre Dame, USA) PhD (Wits). Research Professor, Faculty of Law, North-West University, Mafikeng Campus, South Africa. Email: Avitus.Agbor@nwu.ac.za. ORCiD: https://orcid.org/0000-0001-9647-4849.

1 The Minister of Justice (MINJUST) is a top cabinet position filled by any individual appointed by presidential decree. The appointment does not stipulate the term of office: as has been seen in practice, the occupant of this portfolio serves at the pleasure of the President of the Republic. This ministry deals with, amongst other things, court structures; human rights; court officials such as clerks; registrars; magistrates; the Legal Department and the judiciary.

$2 \quad$ Lumina 2006 African Security Studies 92; Mahmud 1993 Hum Rts Q 485.

$3 \quad$ Nwauzi and Ogon 2018 Cranbrook L Rev 27-40; Eban 2011 AJCJS 127. See generally Sanders and Young "Police Powers".

$4 \quad$ Lumina 2006 African Security Studies 92. 
search and seizures on a person's premises. They may also torture detained individuals or subject them to cruel, inhumane or degrading treatment or punishment, or effect arrests arbitrarily, followed by prolonged detention. The issue of holding law enforcement personnel accountable is to a great extent a reflection of a country's legal system: the rule of law; strong legal institutions like an independent judiciary; the availability of remedies for human rights violations; and open government which permits civil society to openly question misconduct and expose covet operations involving law enforcement personnel. ${ }^{5}$ Without doubt, democratic and autocratic political systems alike are often faced with the challenge of holding law enforcement personnel accountable for human rights violations. The recent trend of racially motivated misconduct by law enforcement personnel in the United States simply indicates that the issue of the accountability of law enforcement personnel is ever present even in advanced and old democracies that are built on respect for human rights; the rule of law; the accountability of public officials; an independent judiciary and a virile civil society. ${ }^{6}$

However, for autocratic regimes that lack such institutional mechanisms as are mentioned above, the situation is grim and grave. Having such broad powers, law enforcement personnel may frequently perpetrate rampant systemic violations of human rights. In such (autocratic) societies, law enforcement personnel are at the disposal of the ruling political party. This compromises their independence, objectivity and functioning as the ruling political elite direct their actions. In cases of misconduct, there is neither the willingness nor the ability to subject the perpetrators to accountability. This evokes the centuries-old rhetorical question of "Who polices the police" in such societies? Even though posed in the context of the police, as discussed below, the notion of law enforcement is much broader than the police corps. A case in point is Cameroon where the task of law enforcement is not exclusively allocated to the police. The composition of the law enforcement forces is different. It comprises personnel from the Police Corps and specialised units of the Armed Forces. The notion of law enforcement therein embraces and captures specialised military, nonmilitary and para-military units. These units include the Groupe Mobile

Lumina 2006 African Security Studies 93.

De Soto 2018 Social Sciences 1; Egharevba Police Brutality, Racial Profiling, and Discrimination; Graziano, Schuck and Martin 2010 Justice Quarterly 52; Onwudiwe 2005 Safer Communities 4; Reitzel, Rice and Piquero 2004 JCJ 607; Tator et al Racial Profiling in Canada. For the experience in France and Canada, see Jobard and Lévy 2011 Can J Criminaol Crim Justice 87; and Tator et al Racial Profiling in Canada. 
d'Intervention (GMI); the Brigade Mobile Mixte (BMM); the Bataillon $d^{\prime}$ Intervention Rapide $(B I R)$; uniformed and ununiformed forces; the gendarmes and the police (National Security). Law enforcement is allocated to a blend of all these units and their agents who also play a vital role in the criminal justice system and (internal) security sector. The composition, however, does not pose a problem. The problem is the inability or unwillingness to hold law enforcement personnel accountable for human rights violations. In this regard, the few cases that have been dealt with administratively, judicially, or both reflect a trend: selective accountability that is influenced by a few factors, some of which are discussed in this paper. It is without doubt that there is quite a distance in Cameroon between the obligations to uphold, respect, promote and protect human rights stipulated in the instruments to which she is a State Party and what happens in reality when violations are perpetrated by law enforcement personnel.

The issue of the accountability of law enforcement for human rights violations touches on many key aspects (democracy, democratisation, the rule of law, equality before the law and equal protection by the law). In the context of establishing a democracy that is founded on the rule of law and respect for human rights, among other things, the notion of the accountability of law enforcement personnel for human rights violations becomes key for a few reasons. First, it attests to the equality of everyone before the law (the rule of law); secondly, it attests to the sanctity of human rights in the democratic order; thirdly, it attests to the ability and willingness of the State to wield control over its agents, especially in cases of misfeasance; and lastly, it evokes the ultimate need for a disciplined law enforcement corps.

Taking an evidence-based approach, this paper looks at the litany of misconduct perpetrated by law enforcement personnel that features in the Annual Reports. With specific focus on those incidents that involved human rights violations, the paper explores the legal arrangements that deal with the accountability of law enforcement personnel for human rights violations in Cameroon. It looks at the accountability trends and identifies some of the arduous challenges on the issue of accountability for law enforcement personnel who commit human rights violations. With a dearth of literature on the issue in the Cameroonian context, this paper offers some useful and practical insights on what can be done in order to advance the notion of accountability for law enforcement personnel, especially in a democratic society where respect for human rights constitutes a fundamental pillar. 
From a human rights perspective, a discussion of the international legal arrangements thereon is required. To examine the issue of the accountability of law enforcement personnel for human rights violations in Cameroon, it is necessary to split this paper into four parts: the first delineates the notions of law enforcement and the accountability of law enforcement personnel, as used in this paper. The second is an analysis of the interface between human rights (with a focus on civil and political rights) and law enforcement, highlighting the uniqueness of monopolised powers, the possibility of abusing such powers and how these result in violations of human rights. The third part explores the normative framework for accountability: it focusses on the soft-law regime built by the United Nations which should guide the training and work of law enforcement officials. The last part deals with accountability in the context of Cameroon by investigating the legislative framework therein and identifying some challenges in ensuring the accountability for law enforcement personnel.

\section{A synoptic discussion on the notion of the accountability of law enforcement}

Commentary B to Article 1 of the United Nations' Code of Conduct for Law Enforcement Officials (UN Code) stipulates that the phrase "law enforcement officials" should be construed in the broadest sense to include all individuals involved in such a function, including military personnel, whether uniformed or not. ${ }^{7}$ In the context of Cameroon, this broad conceptualisation is plausible and fitting. In essence, it means that the State must ensure that individuals in the different units that make up law enforcement should get the appropriate training and skills needed to deal with civilians, especially during political upheavals. Military personnel should undergo further training on working with civilians, the rights of civilians, and the answerability of military personnel to the civilian community for unlawful, improper, or wrongful conduct. The stipulation in the UN Code fits the Cameroonian experience which prefaces the discussion on the notion of the accountability of law enforcement personnel.

The accountability of law enforcement personnel means holding them responsible for their official actions and omissions, whether committed as an organisation or as individuals. Accountability also means the obligation to provide an explanation for their conduct when inquiries are made. This

The United Nations Code of Conduct for Law Enforcement Officials (1979) adopted by General Assembly Resolution 34/169 of 17 December 1979, Commentary B to Article 1. 
extends to justifying the authority which law enforcement personnel purport to have. In this context, the accountability of law enforcement personnel refers to the provision of an explanation for any action or omission that is wholly or partly committed by a law enforcement officer or unit. In the smaller context of individual accountability, it refers to the way law enforcement personnel behave when carrying out their duties, the way complaints are made and investigated, and the kinds of sanctions meted out to the officers in question. These issues are fundamental to ensuring the individual accountability of law enforcement personnel. In the context of the British Police, Sir Robert Mark remarked as follows:

The fact that the British police are accountable to the law, that we act on behalf of the community and are not under the responsibility of the government, makes us the least powerful, the most accountable and therefore the most acceptable police in the world. ${ }^{8}$

Mark's reasoned opinion is the official display of professional norms, official principles and accountability mechanisms working simultaneously to shape and guide the British Police. One doubts if his Cameroonian counterpart would say the same about the Cameroonian Police Corps or any other specialised law enforcement unit.

The foregoing exposition of the composition of law enforcement in Cameroon reveals a unique and distinguishing feature: unlike most other legal systems, where law enforcement is performed primarily by the police corps, in Cameroon it is a task that is performed by civilian and military corps. In this paper the notion of law enforcement is used in a much broader context, without limiting it to the police.

Generally, the question of the accountability of law enforcement personnel looks at what they do with regard to fulfilling their mandated tasks. Narrowed to police accountability, Radelet and Carter define it as

the quality of policing, whether the police are involved in the types of activities or programming that the public wants, whether the police are providing good 'value for money' in the services they provide, and whether the police are holding up their end of the social contract. ${ }^{9}$

The United Nations Office on Drugs and Crime (the UNODC) defines police accountability as

a system of internal and external checks and balances aimed at ensuring that police carry out their duties properly and are held responsible if they fail to do

Anon 2014 http://www.sirrobertmark.co.uk/portfolio/my-grandfather-marcus.

Radelet and Carter Police and the Community 529. 
so. Such a system is meant to uphold police integrity and deter misconduct and to restore or enhance public confidence in policing. Police integrity refers to normative and other safeguards that keep police from misusing their powers and abusing their rights and privileges. ${ }^{10}$

The UNODC holds that effective police accountability is achieved through the involvement of different state and non-state actors in different layers of contemporary democracies such as the judiciary, the legislature, government officials and representatives, civil society, human rights institutions and other oversight bodies. In addition to defining the notion of accountability, the UN has articulated some core elements of accountability. ${ }^{11}$

Still narrowed to the context of the police, the USAID delineates the notion of accountability in much broader contexts (personal and public behaviours; corruption and human rights). ${ }^{12}$

In addition to the foregoing definitions, the accountability of law enforcement has different dimensions, thereby fostering a better and broader understanding of what it entails. ${ }^{13}$ These dimensions are horizontal (relating to the system of governance in which the three branches of government and other state/national institutions exercise some form of accountability over law enforcement), vertical (stipulated internal mechanisms), and external. There are also local and grassroots dimensions of the accountability of law enforcement personnel. ${ }^{14}$

The accountability of law enforcement personnel must undoubtedly be accepted as a key element of democracy, especially if one considers that they are not only agents of the state but endowed with powers that transform them into critical players in the protection of human rights and the rule of law. In this regard, accountability and transparency are twin pillars of an ethical, professionally sound, compliant and legitimate law enforcement force that operates within the purview of lawfulness. ${ }^{15}$ In the words of Jones and van Steden, the accountability of law enforcement personnel is "not

\footnotetext{
10 UNODC Handbook on Police Accountability, Oversight and Integrity 9.

11 UNODC Handbook on Police Accountability, Oversight and Integrity iv-v.

12 USAID 2020 https://www.usaid.gov/sites/default/files/documents/Police_ Accountability_Mechanisms_8.5.2020.pdf 6 .

13 Hope $2020 \mathrm{~J}$ App Secur Res 2.

14 Hope 2020 J App Secur Res 1; Bayley Changing the Guard; Hope 2015 International Journal of Police Science and Management 91-97; and Pino and Wiatrowski "principles of democratic policing" 69-98.

15 Ellison 2007 Police Quarterly 243-269; Prasad 2006 Sur Revista Internacional de Direitos Humanos; and Rowe Policing the Policey 108-131.
} 
only morally desirable, but also instrumentally superior to unaccountable" law enforcement. ${ }^{16}$

\section{Accountability of law enforcement personnel for human rights violations: international legal regime}

The issue of the accountability of law enforcement personnel for human rights violations features in selected international human rights treaties. In addition, there is a strong soft-law legal regime that outlines principles and practices that guide the conduct of law enforcement personnel.

There are three international human rights instruments that are key in understanding the nature of the relationship between law enforcement personnel and human rights violations. These are the International Covenant on Civil and Political Rights (hereafter the ICCPR); the African Charter on Human and Peoples' Rights (hereafter the Banjul Charter); and the Convention Against Torture and Other Cruel, Inhuman or Degrading Treatment or Punishment (hereafter the CAT). Common to the ICCPR and Banjul Charter are provisions that recognise civil and political rights. For example, the right to life. ${ }^{17}$ When using force, law enforcement personnel must ask themselves whether such force is necessary, proportionate and lethal as it may risk compromising the rights to bodily integrity and life. On the right not to be subjected to torture, does law enforcement use torture as a mechanism to obtain information? Are people free to move without being harassed or stopped by law enforcement? Are persons deprived of their liberty treated in a humane and dignified manner? Are suspected or accused persons granted due process in the investigation and prosecution of crimes? Do law enforcement personnel interfere with the right of people to associate? Do law enforcement personnel respect the right of the people to assemble peacefully?

Three fundamental principles are entrenched in both the ICCPR and Banjul Charter. the right to non-discrimination; ${ }^{18}$ the right to equality as espoused in the equality clause; ${ }^{19}$ and the right to an effective remedy for human rights violations. ${ }^{20}$ These principles not only guide the applicability of the substantive human rights contained in those instruments but also require

16 Jones and Van Steden 2013 Policing 563.

17 See Art 6 of the International Covenant on Civil and Political Rights (1966) (the ICCPR); Art 4 of the Banjul Charter and Art 3 of the Universal Declaration of Human Rights (1948) (the UDHR).

18 See Art 2(1) of the ICCPR; Article 2 of the Banjul Charter and Article 2 of the UDHR.

19 See Art 3 of the ICCPR and Banjul Charter respectively.

20

See Art 2(3)(a)-(c) of the ICCPR; Art 8 of the UDHR. 
States Parties to fulfil their obligations described therein by ensuring the respect for, promotion of and protection of civil and political rights. Law enforcement personnel are part of the State and must exercise their duties with due regard to the need to respect, promote and protect civil and political rights. In addition to these two instruments there is the CAT. The CAT defines torture and stipulates a set of obligations and principles for State Parties to prevent and punish torture. The first of the principles stipulates that the defence of obedience to superior orders is not a defence for torture. Thus, a law enforcement officer may not invoke the defence when tried for torture. ${ }^{21}$ The second principle relates to the reception and treatment of complaints of torture. Article 13 of the CAT provides that every individual who alleges torture has the right to complain and to have the case "promptly and impartially examined by, its competent authorities". Pursuant to Article 13 of the $C A T$, the State must take steps to ensure that complainants and witnesses "are protected against all ill-treatment or intimidation as a consequence" of the complaint or evidence given. The third principle and an additional obligation mentioned in the CAT requires State Parties to ensure that their legal systems provide victims of torture with redress. The legal system must provide victims of torture with "an enforceable right to fair and adequate compensation, including the means for as full rehabilitation as possible." Lastly, States Parties

shall ensure that any statement which is established to have been made as a result of torture shall not be invoked as evidence in any proceedings, except against a person accused of torture as evidence that the statement was made. ${ }^{22}$

Cameroon is a State Party to these three instruments. Having ratified the ICCPR, the Banjul Charter and the CAT, the obligations therein, pursuant to Article 45 of the Constitution, constitute law in Cameroon and are accorded a superior status over domestic or municipal legislation. In Cameroon, law enforcement is exclusively allocated to the State. As entities under the direction of the State, law enforcement personnel may swing between acting as guarantors of the respect for, promotion of and protection of human rights on the one hand, and perpetrators of human rights violations on the other hand. Law enforcement falls under the control of the State. In cases where abuses amount to (an) internationally wrongful act(s), such (an) act(s), based on the International Law Commission's Draft Articles

\footnotetext{
21 Article 2(3) of the Convention Against Torture and Other Cruel, Inhuman or Degrading Treatment or Punishment (1985) (the CAT). 
on State Responsibility for Internationally Wrongful Acts, would be attributable to the State. ${ }^{23}$

While the human rights instruments discussed above legally bind States Parties that have ratified them, there is an international soft law regime on police accountability. It comprises norms and principles contained in documents adopted by the United Nations General Assembly. They guide the application of the foregoing human rights instruments. The international soft law regime on the accountability of law enforcement personnel comprises the United Nations' Code of Conduct for Law Enforcement Officials (hereafter the Code of Conduct); ${ }^{24}$ the Basic Principles on the Use of Force and Firearms by Law Enforcement Officials (hereafter the Basic Principles); 25 and the International Code of Conduct for Public Officials (hereafter the International Code of Conduct). ${ }^{26}$ Articles 3 to 8 of the Code of Conduct outline principles that should govern the conduct of law enforcement personnel at all times. These principles require all law enforcement personnel to "fulfil the duty imposed upon them by law, by serving the community and by protecting all persons against illegal acts, consistent with the high degree of responsibility required by their profession."27 The Code of Conduct was later supplemented by the Guidelines for the Effective Implementation of the Code of Conduct for Law Enforcement Officials (hereafter the Guidelines) adopted by a UN General Assembly Resolution. The Guidelines contain many important principles which should guide the training of law enforcement personnel.

The Basic Principles recognises that the work of law enforcement personnel "is a social service of great importance" and a threat to the life and safety of law enforcement personnel "must be seen as a threat to the stability of society as a whole." 28 It acknowledges that law enforcement personnel have

23 See Ch II (Attribution of Conduct to a State), Arts 4-11 of the Draft Articles on Responsibility of States for Internationally Wrongful Acts, adopted by the International Law Commission, 53rd Session, November 2001, Supplement No 10 (A/56/10). See Crawford 2002 AJIL 874-890. United Nations Code of Conduct for Law Enforcement Officials, adopted by General Assembly Resolution 34/169 of 17 December 1979 (the Code of Conduct). Basic Principles on the Use of Force and Firearms by Law Enforcement Officials, adopted by the Eighth United Nations Congress on the Prevention of Crime and the Treatment of Offenders, Havana, Cuba, 27 August to 7 September 1990 (the Basic Principles). The International Code of Conduct for Public Officials, UNGA Resolution A/RES/51/59, 82 ${ }^{\text {nd }}$ Plenary Meeting, 12 December 1996 (the International Code of Conduct).

$27 \quad$ Article 1 of the Code of Conduct.

28 See the Preamble of the Basic Principles. 
"a vital role in the protection of the right to life, liberty and security of the person, as guaranteed in the Universal Declaration of Human Rights and reaffirmed in the International Covenant on Civil and Political Rights."

This instrument guides Member States in developing, ensuring, and promoting the proper role of law enforcement personnel. The principles should also be brought to the attention of all persons involved in the security sector such as judges, prosecutors, lawyers, members of the executive, the legislature and the wider public. The seventeen principles laid down in this instrument should be incorporated into the working manuals of law enforcement personnel as they relate to the use of force and firearms when performing the tasks allocated to them.

In addition, special provisions therein outline the principles governing the use of force and firearms by law enforcement personnel in specific situations. These include the circumstances in which firearms may be used. ${ }^{29}$ the policing of unlawful assemblies, ${ }^{30}$ and policing persons in custody or detention. ${ }^{31}$

The International Code of Conduct regulates the conduct of public personnel and describes a public office as "a position of trust, implying a duty to act in the public interest." The ultimate loyalty to be exuded by public personnel who occupy public offices "shall be to the public interests of their country as expressed through democratic institutions of government." 32 The International Code of Conduct outlines a series of general principles to regulate the conduct of public personnel. These principles, however, are not limited to law enforcement only; they extend to everyone involved in public service. The International Code of Conduct also stipulates principles relating to public officials' disclosure of assets, ${ }^{33}$ the acceptance of gifts or other favours, ${ }^{34}$ the treatment of confidential information, ${ }^{35}$ and involvement in political activities. ${ }^{36}$

\footnotetext{
Principles 9-11 of the Basic Principles.

Principles 12-14 of the Basic Principles.

Principles 15-17 of the Basic Principles.

Article I(1) of the International Code of Conduct.

Article III(8) of the International Code of Conduct.

Article IV(9) of the International Code of Conduct.

Article V(10) of the International Code of Conduct.

Article VI (11) of the International Code of Conduct.
} 


\section{Human rights violations committed by law enforcement personnel}

The Annual Reports on human rights in Cameroon published by the Ministry of Justice document some of the cases of misconduct of law enforcement personnel. "Misconduct" in this context refers to (all) unlawful or unprofessional acts or behaviour perpetrated by law enforcement personnel. That, without doubt, is quite a broad frame of reference. A summary of instances of misconduct that constitute human rights violation $s$ might include illegal remand, maladministration, abusive arrests and release against payment, the harassment of road users, the abusive use of a service weapon occasioning bodily harm, violence and assault on service users. the daytime control of vehicles in violation of instructions relating to the organisation and functioning of Police Controls, a failure to respect instructions relating to road controls resulting in loss of human life and serious bodily injury, illegal attempts to arrest a person, brutality, violence and assault. the stealing of motorcycles, influence peddling, false arrests and blackmail, participation in banditry in rural areas, harassment, racketeering and the extortion of funds, the unauthorised withdrawal and illegal retention of official documents, the oppression and appropriation of another person's property through fraud, assault on colleagues, corruption, fighting in a state of drunkenness, the invasion of residences, assault occasioning death, simple harm or slight harm, a refusal to assist. a failure to assist, murder, a disturbance of quiet enjoyment, assault and battery, the misuse/abuse of firearms, assault on public officers, assault on a secretary of a high school, the theft/retention of another's property, fighting with an individual. the unlawful withdrawal of the identification documents of an individual, violence occasioning the death of detainees, the seizure of another person's property, threats with arms, and sexual indecency to a minor (under sixteen years of age). ${ }^{37}$

These acts of misconduct attracted some kind of administrative sanctions,

37 MINJUST Report by the Ministry of Justice on the State of Human Rights in Cameroon 2005 23-26; MINJUST Report by the Ministry of Justice on Human Rights in Cameroon in 2006 10-27; MINJUST Report by the Ministry of Justice on Human Rights in Cameroon in 2007 39-60; MINJUST Report by the Ministry of Justice on Human Rights in Cameroon in 2008 35-52; MINJUST Report by the Ministry of Justice on Human Rights in Cameroon in 2009 47-68; MINJUST Report by the Ministry of Justice on Human Rights in Cameroon in 2010 77-82; MINJUST Report by the Ministry of Justice on Human Rights in Cameroon in 2011 70-84; MINJUST Report by the Ministry of Justice on Human Rights in Cameroon in 2012 24-30; and MINJUST Report by the Ministry of Justice on Human Rights in Cameroon in 2013 27-36. 
ranging from demotions and delayed increments to reprimand. In the Ministry of Defence, which is responsible for the military and the National Gendarmerie, many cases of misconduct perpetrated by personnel were prosecuted by different Military Tribunals across the country. Some of the cases prosecuted involved torture, the violation of the rights of individuals, false imprisonment, sequestration. violence on junior staff, the abuse of office and extortion. Criminal sanctions such as imprisonment and fines have been imposed. Damages have also been levied. In some cases, the terms of imprisonment were suspended.

\subsection{Criminal prosecutions and civil claims}

The State has subjected several senior and lower ranks of police personnel to judicial proceedings. Some have been sanctioned with the imposition of terms of imprisonment, fines, or in some cases both. A few of the cases are:

- Police Constables Eroume À Ngong and Mvoutti Alexandre and Superintendent of Police Moutassie Bienvenue, were convicted of torture and sentenced to five years' imprisonment in Judgment No. 176/Crim of 5 June 1998;

- Superintendent of Police Nsom Bekoungou was convicted of torture and sentenced to six years' imprisonment in Judgement No. 195/Crim of 26 June 1998 (High Court of Mfoundi);

- Superintendent of Police Menzouo Simon and Senior Police Constable Saboa Jules Oscarwere convicted of torture and sentenced to five years' imprisonment each by the High Court of Upper-Nkam on 27 February 2002;

- Police Constable Avom Jean Christophe was convicted of torture and sentenced to ten years' imprisonment by the High Court of Nyong and So'o on 6 March 2003;

- Police Constables Kam John Brice, Mimoga Louis Legrand and Greboubaï Michel were convicted of torture of a detainee and sentenced to five years imprisonment each by the High Court of Mfoundi in Judgment No. 318/Crim of 26 August 2003;

- Police Constable Effa Ngono Akame Geoffrey was convicted of unintentional killing by the Military Tribunal of Yaoundé and sentenced to two years' imprisonment, suspended for three years, and CFA 3000000 in damages; 
- Inspector of Police Stephen Ngu was convicted of torture and grievous harm by the High Court and sentenced to five years' imprisonment on 24 October 2005; and

- Police Constable Habit Tankeu was charged with murder committed with his service gun by the High Court of Mfoundi.

In addition to these criminal proceedings, civil claims were lodged against some members of the police corps for torture:

- Inspector of Police ATEP was sentenced to a fine of CFA 10000 for slight harm (Mokolo Court of First Instance);

- Inspector of Police Meigari Beda of Meiganga was sentenced by the Adamawa Court of Appeal to two years' imprisonment, suspended for three years, and a fine of CFA 90000 , for torture, threats, blackmail and false arrest;

- Inspector of Police Amadou Abba was sentenced by the North Court of Appeal to six months' imprisonment, suspended for three years, on a charge of simple harm; and

- Police Inspector Roger Zameyo and Police Constable Thomas Nyamekong were sentenced by the Court of First Instance, Yaoundé, on charges of abuse of office, refusal of service and torture, to two years' imprisonment and damages in the sum of CFA 2090000.

The following police personnel were prosecuted for human rights violations (although their cases had not been finalised by the time the Annual Reports were compiled):

- The People v Police Constable Samba Ngono Innocent Bernadin, charged with unintentional killing;

- Senior Police Inspector Mbarga Alogo Maxime, charged with destruction, slight harm and illegal detention of property;

- The People $v$ Inspector of Police Zameyok and Senior Police Constable Nyamekong, charged with torture, oppression and threats;

- The People v Police Officer Nanga Thérèse, Medou Obou and Tchokomeni, jointly charged with torture, oppression, simple harm, failure to assist and destruction; 
- The People v Inspector of Police Amougou Belinga Azérie, accused of lack of self-control and charged with unintentional killing;

- The People $v$ Superintendent of police Ondo Obah and Senior Inspector of Police Abate, jointly charged with oppression, cruelty and harm; and

- The People v Senior Police Inspector Bafon Philip, charged with murder with the use of his service gun.

The litany of misconduct listed above indicates indiscipline, unprofessionalism, irresponsibility and a lack of ethics in law enforcement. These misdeeds have brought the different units into considerable disrepute and national contempt. The misconduct also reveals the nature, gravity and repetitiveness of the human rights violations perpetrated by law enforcement personnel. It highlights the absence of an oversight body to which law enforcement personnel should account and tells a story of the sheer disregard for human rights perpetrated by individuals who exercise public powers. It raises questions about the integrity of the recruitment process, particularly given that marauders and hoodlums infiltrate public offices without thorough background checks to identify and detect their previous character deficiencies, arrests, and convictions. While the list of instances of misconduct is only a partial representation of the misdeeds of the law enforcement personnel, it is an accurate portrait of individuals stuffed into a system whose primary focus is doing whatever they can to enrich themselves at the expense of the corporate and national image. These acts of misconduct indicate that there is an urgent necessity to revamp law enforcement with a focus on mainstreaming the role of ethics and the principles that should always guide their work. The selection of recruits, their training and the way they work must place emphasis on the importance of a professional and disciplined law enforcement corps in the security and criminal justice sectors. An unethical, irresponsible and unaccountable law enforcement force is a danger to society particularly when individuals with questionable standards of integrity filter into the sector through cracks and quickly degenerate into agents of insecurity and betrayal, holding the security and safety of the people ransom.

\section{Holding law enforcement personnel accountable for human rights violations}

The foregoing paragraphs explore the theoretical framework of the accountability of law enforcement personnel. By looking at the core 
international human rights instruments and the international soft law regime that contain the numerous norms and principles that should guide the respect for, enforceability, promotion and protection of human rights, it is suggested that these two sets of rules (binding and non-binding) must be used as the yardstick to develop, direct and define the conduct of law enforcement personnel at all times. The State should put in place mechanisms for protecting human rights, establishing and maintaining peace, security and order, and guaranteeing stability. These mechanisms constitute what is known as the security sector. ${ }^{38}$ Law enforcement personnel are important actors in the security sector. Their most basic functions include the maintenance of public order in society, the prevention and detection of crime, and the provision of assistance to the public. Law enforcement personnel play an important role in the criminal justice system. They conduct investigations; identify and interrogate witnesses and suspects, conduct searches and seizures, and arrest and detain perpetrators of crimes.

The police arrest, detain, search, seize, and even use force in certain circumstances. ${ }^{39}$ In most societies the exercise of these powers falls within the exclusive jurisdiction of the police. However, Cameroon is unique as these tasks are jointly and routinely performed by a blend of police, military, and para-military units. With the nature of the powers that they have, especially in the context of maintaining peace and security, and the pivotal role they play in the criminal justice sector, they are strongly inclined to commit such human rights violations as they can, and easily to interfere with civil liberties. Consequently, there is a need for effective and adequate mechanisms to ensure that law enforcement personnel use their powers professionally and lawfully in the service of public interest. This means that

38 States, however, in furtherance of their sovereignty, decide on how to constitute their security sectors, and this differs amongst States. Yet there is some general consensus that the security sector comprises the key security actors, which include the police, the gendarmerie, the armed forces, border guards, customs and immigration, intelligence and security services, security management and oversight bodies such as ministries of defence and internal affairs, financial management bodies and public complaints commissions, justice and law enforcement institutions like the judiciary, prisons, prosecution services and traditional justice systems, and non-statutory security forces such as private security companies, guerrilla armies and private militias.

39 See, for example, s 30(2) of Law No 2005/007 of 27 July 2005 on the Criminal Procedure Code (hereafter the Criminal Procedure Code or CPC). Also see Nwauzi and Ogon 2018 Cranbook L Rev 27-40; Jacobi 2000 Wis L Rev 789-854; Sanders and Young "Police Powers" 309-340; Eban 2011 AJCJS 127; and Ngwang 2021 American Journal of Public Policy and Administration 1-11. 
any reported allegations of misconduct involving law enforcement personnel must be investigated and the appropriate form of redress and sanction imposed.

Law enforcement personnel perform tasks that require a high degree of integrity and oversight. ${ }^{40}$ When integrity is compromised or oversight is lacking, they become tempted to act beyond their remit. This results in professional misconduct that varies from trivial to grave breaches of criminal and international human rights law. These violations, however, may occur at the instigation of the State to which law enforcement personnel are accountable. They are at the disposal of the executive and perform their functions under the Delegation of National Security, the Ministry of Defence and the Presidency. Appointments and deployments are made by top political elites of the ruling party. The result of this is the high degree of politicisation of law enforcement personnel as appointees show loyalty to their political "godfathers" by ensuring that they always protect and serve their interests at all levels. This means that in cases of political violence or riots, dissidents who antagonise such political actors are easily identified and quickly restrained through arrests and detention; brutalisation; and at times, being shot to death. Drawn from different governmental structures and trained to respond to different situations, the blend of law enforcement personnel in Cameroon has succeeded in eroding the civilian character of the Police Corps. With military-style tactics used to confront even trivial transgressions, law enforcement personnel have evolved to be part of the human rights problem in Cameroon: a visible enemy amongst the Cameroonian people who serve the interests of a few rather than the public and are now consigned to the status of the most conspicuous agents of public insecurity, disorder and selective enforcement of the law.

Accountability mechanisms for human rights violations committed by law enforcement personnel constitute only one dimension of ensuring that these personnel act professionally and within the remit of their mandate. When they exceed the boundaries of their authority, law enforcement personnel answer for such transgressions. ${ }^{41}$ There is an urgent need to reform the specialised units that deal with law enforcement. Some of these reforms include the need for constant training and retraining with focus on international human rights norms and laws and the establishment of an institutional oversight framework to make the units accountable to

\footnotetext{
40 See generally Klockars, Ivković and Haberfeld Enhancing Police Integrity; Klockars, Ivkovic and Haberfeld Contours of Police Integrity.

41 Eban 2011 AJCJS 127.
} 
themselves, the State and the public. Efforts should be made to develop and maintain independent law enforcement personnel and units that operate professionally and with integrity. In addition, corruption in the sector must be fought in order to change law enforcement from an untrusted, discredited and venal corps to a trustworthy and respectable institution staffed by individuals who are bound to the corps and confined to the remit of their power.

\subsection{Legislative arrangements to ensure the accountability of law enforcement personnel for human rights violations}

In Cameroon the accountability of law enforcement personnel is ensured through national legislation. The Penal Code deals with law enforcement personnel as public servants, criminalises torture, and removes the defence of obedience to lawful authority in cases where superior orders have been manifestly unlawful. Legislation also spells out the effect of violating the provisions of the CPC (the Criminal Procedure Code).

\subsubsection{The criminalisation of torture in the Penal Code}

In addition to the ratification of the CAT, Cameroon has domesticated the contents of the CAT by criminalising torture in its legal system. The Penal Code defines the constitutive elements of torture. ${ }^{42} \mathrm{It}$ further stipulates the various sanctions to be imposed for the crime of torture. ${ }^{43}$ The Penal Code makes the defence of obedience to superior authority irrelevant. ${ }^{44}$ Without doubt, there are legislative arrangements that criminalise torture, a key and commendable legislative measure put in place to give effect to the CAT. Unfortunately, the widespread perpetration of torture stirs a suspicion as to whether law enforcement officials are exploring the inherent weaknesses in the legal system or will be protected by political superiors on whose orders such acts of torture are often perpetrated.

\subsubsection{Qualifying the defence of obedience to lawful authority}

In Cameroonian criminal law, one of the absolute defences that exonerates an accused from criminal responsibility is obedience to lawful authority. In other words, no criminal responsibility would be imposed on an accused person if it is established that the conduct for which the accused is charged

42 Sections 277-3(5) of Law No 2016/007 of 12 July 2016 on the Revised Penal Code (hereafter the Penal Code).

43 See ss 277-3(1)-(4) of the Penal Code respectively on the different sanctions.

44 Sections 277-3(7) of the Penal Code. 
was perpetrated in obedience to lawful authority. Section 83 of the Penal Code stipulates the defence of obedience to lawful authority.

Pursuant to the provisions of section 83 of the Penal Code, the defence is not applicable in cases where the order is "manifestly unlawful". Although the Penal Code does not define what is "manifestly unlawful", it could be reasoned that the intention of the lawmaker is to ensure that subordinates who take orders from their superiors interrogate the lawfulness of the orders and report to higher authorities rather than perpetrate unlawful conduct simply because they have been given orders to act unlawfully by their immediate superiors. In this context, the words "manifestly unlawful" mean contrary to or in violation of the law. In this context, law means both national and international law.

In Judgment No 297-97 of 26 August 1997 delivered by the Yaoundé Military Tribunal, a Gendarme official was sentenced to 15 years' imprisonment for ordering the summary execution of seven individuals presumed to be highway robbers. Five members of his unit were convicted of capital murder and sentenced to terms of imprisonment of 10 to 12 years. The judges rejected the contention that they executed the suspects on the orders of their superior and held that such orders were manifestly unlawful. ${ }^{45}$ The judgment of the Military Tribunal in the infamous "Bépanda 9" case was also reasoned on similar lines. The perpetrators were charged with violating instructions, being accessories to torture, being accessories to capital murder, and corruption. They were tried by the Military Tribunal on 6 July 2002 in compliance with Decision No 139-02. Two of the eight accused were convicted and sentenced to military detention for 15 months, suspended for 3 years. Other were sentenced to military detention for 16 months. Some gendarmes (from the grade of non-commissioned officers to senior officers) were remanded in custody, charged and prosecuted for torture and other human rights violations.

\subsubsection{Aggravation for public servants}

The Penal Code also stipulates aggravating circumstances. One of the aggravating circumstances is the commission of a crime by a public servant as provided for in section 89 of the Penal Code. From the foregoing, the commission of any crime by any public servant constitutes an aggravating circumstance. This means that the status of the offender as a public servant warrants the imposition of a higher penalty for the offence. Within the

45 MINJUST Report by the Ministry of Justice on the State of Human Rights in Cameroon 2005 23-26. 
purview of section 89 of the Penal Code, law enforcement personnel are public servants and attract higher penalties when convicted of crimes.

\subsubsection{The admissibility of evidence obtained through torture}

In Cameroon the use of torture by law enforcement personnel to obtain statements or confessions from accused persons is common. The challenge is whether to grant legal recognition to statements or confessions obtained through torture or other forms of duress. Generally judicial officers disregard statements and confessions given involuntarily. The case of The People vs Tonfack Julienne and Kamdem Robert illustrates this point. ${ }^{46}$ There was a land dispute between Robert Kamdem and Mrs Tonfack Julienne. The latter lodged a complaint at the Dschang Investigation Brigade where her brotherin-law, Sergeant Djuto Richard, served as Assistant Commander. She explained that Kamdem threatened her and her children with a locally made pistol which he shot in the air to intimidate her. Djutio Richard proceeded to arrest Kamdem Robert. The evidence adduced at the trial established that Djutio Richard subjected Kamdem Robert to inhuman treatment because of his relationship with Mrs Tonfack Julienne. He was remanded in custody for 20 days (which exceeds the legal time-limit) and beaten several times to force him to confess. He sustained injuries because of this treatment and finally confessed to the crime, which he had not committed. The conditions under which he made the confession were a glaring example not only of torture but also a flagrant violation of human rights in obtaining an involuntary confession. The Court annulled the confession, set aside the Kamdem report and released him. ${ }^{47}$

\subsubsection{The legal implications of the contravention of the CPC}

The CPC regulates, amongst other things, the investigation of offences, ${ }^{48}$ the search and identification of offenders, ${ }^{49}$ the method of adducing evidence, 50 the organisation, composition and jurisdiction of courts in criminal matters, ${ }^{51}$ and the rights of the parties. ${ }^{52}$ Numerous provisions of The People vs Tonfack Julienne and Kamdem Robert Judgment No 69/00 of 21 September 2000.

47 MINJUST Report by the Ministry of Justice on the State of Human Rights in Cameroon 2005 23-24.

48 Section 1 (a) of the CPC.

49 Section $1(\mathrm{~b})$ of the $C P C$.

50 Section $1(\mathrm{c})$ of the $C P C$.

51 Section $1(\mathrm{e})$ of the $C P C$.

52 Section 1 (i) of the CPC.
} 
the CPC define the conduct of law enforcement personnel ${ }^{53}$ in criminal processes such as effecting the arrest of a suspect, ${ }^{54}$ the search of premises, ${ }^{55}$ the seizure of items during searches, ${ }^{56}$ and the interception, recording or transcribing of all correspondence sent by means of telecommunication. ${ }^{57}$ The CPC stipulates that a failure to comply with its procedures during searches and seizures renders the proceedings null and void. ${ }^{58}$ The provisions of sections 3 and 4 of the CPC, which prescribe absolute and relative nullity in situations where there has been an infringement of any provisions of the $C P C$, generally apply. Absolute nullity can be raised at any stage of a criminal trial when an infringement of the $C P C$ is "prejudicial to the rights of the defence as defined by legal provisions in force" or is contrary to public policy. ${ }^{59}$

This section indicates the judicial and legislative dimensions of the accountability of law enforcement personnel in the criminal trial process by defining their powers and responsibilities and the legal effect of any infringements at the criminal trial.

\subsection{Accountability mechanisms for human rights violations: the trends}

Accountability for violations of human rights has been trending in recent years. Accountability refers to both the institution of administrative and judicial proceedings against perpetrators and the imposition of sanctions. This section deals with the administrative accountability to which law enforcement personnel are subjected due to their violations of human rights.

\subsubsection{Criminal prosecutions and civil claims}

The State has subjected several senior and lower ranks of police personnel to judicial proceedings. Some have been sanctioned with the imposition of terms of imprisonment, fines or both - in some cases. In addition to criminal proceedings, civil claims for torture were lodged against some members of the police corps. Other police personnel were prosecuted for human rights violations.

\footnotetext{
53 See s 79 of the $C P C$ for a definition of who qualifies as a judicial police officer and $s$ 82 of the $C P C$ for the responsibilities entrusted in criminal procedure.

54 See generally ss $30-38$ of the CPC.

55 See ss $93-99$ of the CPC.

56 See ss $93-99$ of the CPC.

57 Section $92(3)$ of the $C P C$.

58 Section 100 of the CPC.

59 See $\mathrm{s} 3(1)(\mathrm{a})-(\mathrm{b})$ of the CPC.
} 


\subsubsection{Administrative accountability}

Depending on several factors, administrative superiors usually subject law enforcement personnel to some form of administrative accountability for human rights violations and other misconduct. The Annual Reports indicate that the administrative penalties imposed for the different kinds of human rights abuses comprise administrative detention, suspension for a defined period without salary, demotion, ineligibility for promotion, revocation of pension, and in some instances, dismissal. Unfortunately, the laws that govern the choice of administrative sanctions are not made public. Often the public is kept wondering, especially when they compare the various administrative sanctions vis-à-vis the misconduct and observe that grave misconduct is punishable with a three-month suspension. Some of the cases of police misconduct were sanctioned with administrative penalties which, in some cases, precluded judicial processes that would have resulted in conviction and the imposition of a term of imprisonment, including a fine and the award of civil damages if there was a civil claim. Suspensions for up to three months have been meted out to senior members for misconduct which included gross negligence in giving out a service weapon used to kill a police constable, a serious unscrupulous act involving the killing of an individual during a police operation, shooting a person, gross negligence in the erroneous withdrawal of a document, the appropriation of a seized object, shooting and killing of a person at night, and shooting and killing a colleague.

\section{Challenges to the effective accountability of law enforcement personnel}

Although some law enforcement personnel have been held accountable for human rights violations, numerous cases have gone unreported and without the imposition of accountability. Selective accountability for human rights violations is a big challenge. Several factors contribute to the lack of accountability. Some of these factors include the politicisation of law enforcement, executive control, the absence of oversight bodies (internal and external), official secrecy, unlawful interference with the work of law enforcement, the absence of professionalism because of inadequate basic training, and a weak commitment to the standards and expectations of the profession. 


\subsection{Politicisation and external interference with law enforcement operations}

The executive directs the operations of law enforcement personnel. The President appoints senior police and military officers who serve at his pleasure. He has the prerogative to make appointments to senior positions and terminate the appointments when he deems it fit and necessary. As such, the President, the Ministers and the other members of the executive possess wide powers relative to the control and functioning of law enforcement personnel. Most appointees are chosen based on political grounds as opposed to their skill and competence. The politicisation of the process builds a culture of loyalty to the appointer rather than to the people and the community. Through the appointment system, law enforcement personnel have become a tool in the hands of political elites. Often law enforcement personnel are used to victimise political dissidents during political unrest. Consequently, there is a lack of accountability for most human rights violations committed by law enforcement personnel during political crises. Accountability is impossible because elements of law enforcement are used by the ruling political elite as forces of "law and order" to restore peace and security while pursuing an agenda to maintain the status quo.

Political and other forms of external and illegitimate interference in peace and security operations are not a new phenomenon in Cameroon. Auerbach defines illegitimate interference with police operations as "the exertion of influence over the police ... by actors outside the chain of command ... through extra-legal or illegal means; or for the achievement of extra-legal or illegal ends."60 There have been instances of illegitimate interference, concluded through private transactions, about which the broader public is deprived of information, such as the source, the nature and the beneficiaries of such transactions. Secret operations have become a typical feature of law enforcement personnel. Examples include the release of suspects affiliated to top politicians, the obstruction of political dissidents, the arrest and detention of individuals for their political opinions, and the use of law enforcement personnel to settle political disputes by conducting massive arrests and prolonged detentions without arraignment before a judicial authority. Since political interference in law enforcement is selective, accountability for the human rights violations committed by law enforcement personnel is also selective. This is a challenge, particularly given the difficulties of containing incidents of political and illegitimate interference.

$60 \quad$ Auerbach 2003 AHRLJ 293. 
These incidents compromise the work, professionalism, and integrity of law enforcement personnel.

The infiltration of law enforcement by politicians and their instrumentality in the settlement of political differences taints the image of the entire corps and erodes public confidence in law enforcement. Political appointments of senior personnel in law enforcement compromise their independence, which is vital for them to perform their duties. To build an independent, professional, ethical, and disciplined law enforcement organisation, there is a need for the Cameroonian government to change the recruitment of senior personnel to guarantee their independence and security of tenure. One way of doing this would be to establish an open recruitment process through which the most competent persons get hired. Another way could be through establishing a vetting process, the vetting to be done by a blend of the judicial and legislative arms of government, to whom the selected personnel would be accountable and on whom they would be dependent for the security of their tenure.

\subsection{Official secrecy in law enforcement}

Law enforcement personnel engage in many surreptitious operations, particularly when they commit human rights violations. There is no obligation on the senior ranks of law enforcement to share the details of their operations, such as consultations on appointments and basic operational activities. Instead, a culture of official secrecy has been established and entrenched, which runs contrary to the principles of democratic and transparent government.

Ministries like the Ministry of Justice release some information regarding the operations of the law enforcement to the public. However, the annual reports of the Ministry of Justice are scanty and only give compendious narratives of which law enforcement personnel have been subjected to which kind of discipline. The annual reports also contain statistics on crimes in the country. Although these reports are available to the public, there is no engagement or discussions with the public on the reports, especially on the relevant aspects of accountability and the combatting of crime.

In addition to the issue of official secrecy, the establishment of numerous secret law enforcement units causes further problems. The secret units are vested with extensive powers and often commit human rights abuses. The purpose of the establishment of the secret groups is to enhance the coercive strength of the executive. Their operations are coated with hard layers of 
opacity, which make it difficult to understand what they do. It is impossible to initiate legal action against these clandestine units for violations of human rights. The lack of institutional transparency usually results in confusion amongst the units.

Due to the culture of the secrecy of law enforcement operations, it becomes difficult for members of the community to obtain reliable information on their operations. Executive interference and the conduct of clandestine operations compound the lack of mechanisms to hold such secret units accountable. The few accountability mechanisms are administrative, discriminatory or selective in practice, and depend on whether the superiors want their agents to be prosecuted. The reality of law enforcement operations is shaped by numerous contextual factors which include the volatile and tense political climate in which people are suspicious of the other, the utilisation of law enforcement to quell political opponents, the reduction of law enforcement into agents of political dispute resolution, the nomination of politicians to key positions in the law enforcement structures, the disruptive politicisation of law enforcement, and a climate of bribery and corruption in which people pay unacknowledged and unaccounted funds to use the services of law enforcement.

\subsection{Absence of external accountability mechanisms}

Another big challenge to hold law enforcement personnel accountable for human rights violations is the absence of external accountability mechanisms. While selective accountability could take place, depending on what was done, by whom and the motives underlying such conduct, entities external to law enforcement tasked with ensuring accountability are either absent or are also constrained by the political climate in which they operate. For example, the Legal Department conducts prosecutions but is influenced by a negative attitude towards prosecuting law enforcement personnel for human rights abuses. The National Commission on Human Rights and Freedoms, another external mechanism, has been reluctant to pronounce on incidents of human rights abuses committed by law enforcement personnel. One therefore wonders which institutions and procedures are accessible to members of the community to ensure that human rights violations committed by law enforcement personnel are reported, investigated and prosecuted, and that appropriate sanctions are imposed. The Legal Department and the National Commission of Human Rights and Freedoms are politicised by the executive and share a common motive. They are selective in their choice of cases in which they hold law enforcement personnel accountable. In conclusion, a major challenge in this 
regard is to seek a permanent divorce from political actors not only in the work of law enforcement personnel but also in the external oversight mechanisms to ensure accessibility; uniformity; reliability and consistency in all cases of human rights abuses.

\subsection{The absence of internal accountability mechanisms}

The beleaguered law enforcement units are notorious for their impunity. The lack of accountability severely impacts on the need for a uniform and consistent approach to bring law enforcement personnel to justice for human rights violations. Selective accountability illustrates the absence of mechanisms to hold law enforcement personnel accountable. What does the law say regarding the misconduct of law enforcement personnel? The internal accountability mechanisms should establish an entity as well as a procedure to ensure that complaints are handled according to the law. Some questions come to mind: to whom does a victim complain? How does a victim file a complaint? Is there any financial expense involved in such a process? What is the composition of the internal body? How does it operate? How independent is it from interference, both from within and from without? What are the available sanctions if the law enforcement official is found guilty? Are the findings of such an internal body reviewable, and if so, by which body? These questions need to be answered to determine if there are any such internal institutional accountability mechanisms and how effective they are in dealing with cases of human rights violations committed by law enforcement personnel. According to Bayley, "effective disciplinary systems in the police should be a first-order priority in democratic reform."61 Auerbach observes that

[w] hen properly functioning, mechanisms of internal accountability both prevent the violation of human rights and, by sustaining productive relations between the police and the public, enhance the ability of the police to prevent and investigate crime. 62

\section{Conclusion}

As Eban says,

[t]he horizon of ethical thought in our time is framed by the respect for human rights and the rule of law. Therefore [,] the yardstick for measuring the extent to which law enforcement officers respect human rights and the rule of law in the course of the performance of their duty is the consistency and conformity with which criminal trial procedure successfully hold agents accountable for

61 Bayley Democratizing the Police Abroad 20-23, 40-41.

62 Auerbach 2003 AHRLJ 292. 
abuses of human rights and the rule of law. The enormous power wielded by the police, their possession and use of firearms, and the inevitable practice of discretion in decisions relating to arrest, searches and pre-trial detention require that law enforcement officers operate within the law.... ${ }^{63}$

Legal accountability, as evidenced by prosecutions and civil claims, combined with administrative mechanisms to hold law enforcement personnel accountable, is developing. Unfortunately, these remain selective. Coupled with political interference and the absence of any external oversight mechanisms (especially from civil society), the accountability of law enforcement personnel for human rights violations becomes a thorny and contentious issue. This issue requires an urgent attention in the democratic dispensation in Cameroon, as contemporary democracies are built on respect for human rights. If agents of a state such as law enforcement personnel are not held accountable for human rights violations, then the democratic character of that state becomes questionable.

To hold law enforcement personnel accountable for their actions, it is vital for them to get proper direction, equipment, and preparation permitting them to perform their tasks professionally. They also need the assurance of decent working conditions. Their actions must be constantly reviewed and evaluated by their line managers and superiors. Effective accountability can be achieved if there is a proper complaints system that is accessible to the public and is effectively designed to investigate allegations of human rights violations and to recommend disciplinary sanctions or make referrals for prosecution. An effective complaints system must be established to achieve effective accountability.

As shown above, law enforcement personnel are prone to commit human rights violations in the performance of their tasks due to the inherent powers they possess. Thus, the establishment of mechanisms to hold law enforcement personnel accountable for human rights violations is a key to good governance and the rule of law. Given the link between law enforcement personnel and human rights abuses, the need to hold them accountable for human rights violations is important to ensure that they respect, promote and protect human rights. A well-regulated, disciplined and accountable law enforcement corps reflects not only a high level of civility, decency and the centrality of human rights but also a culture of good governance and adherence to the rule of law. In exploring the notion of the accountability of law enforcement personnel, especially for human rights 
violations, two issues arise: lawfulness and legitimacy. Law enforcement personnel require a measure of independence in doing their job, but they should nevertheless be accountable for their conduct (whether an action or an omission). The accountability of law enforcement personnel for human rights violations is not only a thorny issue that exposes the frailties of a legal system, weak legal institutions and the absence of the rule of law but, it also highlights the venality of the law enforcement corps, given their selective accountability.

\section{Bibliography}

\section{Literature}

Auerbach 2003 AHRLJ

Auerbach JN "Police Accountability in Kenya" 2003 AHRLJ 275-313

Bayley Changing the Guard

Bayley DH Changing the Guard: Developing Democratic Police Abroad (Oxford University Press Oxford 2005)

Bayley Democratizing the Police Abroad

Bayley DH Democratizing the Police Abroad: What to Do and How to Do It (US Department of Justice Washington DC 2001)

Crawford 2002 AJIL

Crawford J "The ILC's Articles on Responsibility of States for Internationally Wrongful Acts: A Retrospect" 2002 AJIL 874-890

De Soto 2018 Social Sciences

De Soto W "Do Police Officers in the USA Protect and Serve all Citizens Equally?" 2018 Social Sciences 1-11

Eban 2011 AJCJS

Eban E "Criminal liability of the Police in Cameroon: Prospects and Challenges" 2011 AJCJS 127-146

Egharevba Police Brutality, Racial Profiling, and Discrimination Egharevba S (ed) Police Brutality, Racial Profiling, and Discrimination in the Criminal Justice System (IGI Global Hershey PA 2017) 
Ellison 2007 Police Quarterly

Ellison G "A Blueprint for Democratic Policing Anywhere in the World? Police Reform, Political Transition, and Conflict Resolution in Northern Ireland" 2007 Police Quarterly 243-269

Graziano, Schuck and Martin 2010 Justice Quarterly

Graziano L, Schuck A and Martin C "Police Misconduct, Media Coverage, and Public Perceptions of Racial Profiling: An experiment" 2010 Justice Quarterly 52-76

Hope 2015 International Journal of Police Science and Management Hope Sr KR "In Pursuit of Democratic Policing: An Analytical Review and Assessment of Police Reforms in Kenya" 2015 International Journal of Police Science and Management 91-97

Hope 2020 J Appl Secur Res Hope Sr KR "Civilian Oversight for Democratic Policing and Its Challenges: Overcoming Obstacles for Improved Police Accountability" $2020 \mathrm{~J}$ Appl Secur Res 1-33

Jacobi 2000 Wis L Rev

Jacobi JV "Prosecuting Police Misconduct" 2000 Wis L Rev 789-854

Jobard and Lévy 2011 Can J Criminol Crim Justice

Jobard F and Lévy R "Racial Profiling: The Parisian Police Experience" 2011 Can J Criminol Crim Justice 87-93

Jones and Van Steden 2013 Policing

Jones T and Van Steden R "Democratic Police Governance in Comparative Perspective" 2013 Policing: An International Journal of Police Strategies and Management 561-576

Klockars, Ivkovic and Haberfeld Contours of Police Integrity

Klockars CB, Ivkovic SK and Haberfeld MR The Contours of Police Integrity (Sage Thousand Oaks 2003)

Klockars, Ivković and Haberfeld Enhancing Police Integrity

Klockars CB, Ivković SK and Haberfeld MR Enhancing police integrity (Springer Dorrecht 2007) 
Lumina 2006 African Security Studies

Lumina C "Police Accountability and Policing Oversight Mechanisms in the Southern African Development Community" 2006 African Security Studies 92-108

Mahmud 1993 Hum Rts $Q$

Mahmud SS "The State and Human Rights in Africa in the 1990s: Perspectives and Prospects" 1993 Hum Rts Q 485-498

Ngwang 2021 American Journal of Public Policy and Administration Ngwang $R$ "Arresting Roadside Corruption: What Prospects Remain for Anglophone Cameroon?" 2021 American Journal of Public Policy and Administration 1-11

Nwauzi and Ogon 2018 Cranbrook L Rev

Nwauzi $L$ and Ogon P "A Critical Analysis of the Scope of Police Powers of Law Enforcement in Nigeria" 2018 Cranbrook L Rev 26-41

Onwudiwe 2005 Safer Communities

Onwudiwe I "Defining Terrorism, Racial Profiling and the Demonisation of Arabs and Muslims in the USA" 2005 Safer Communities 4-11

Pino and Wiatrowski "Principles of Democratic Policing"

Pino NW and Wiatrowski MD "The Principles of Democratic Policing" in Pino NW and Wiatrowski MD (eds) Democratic Policing in Transitional and Developing Countries (Ashgate Farnham 2006) 69-98

Prasad 2006 Sur Revista Internacional de Direitos Humanos

Prasad D "Strengthening Democratic Policing and Accountability in the Commonwealth Pacific" 2006 Sur Revista Internacional de Direitos Humanos 108-131

Radelet and Carter Police and the Community

Radelet LA and Carter DL The Police and the Community (Macmillan College Publishing New York 1994)

Reitzel, Rice and Piquero $2004 \mathrm{JCJ}$

Reitzel JD, Rice SK and Piquero AR "Lines and Shadows: Perceptions of Racial Profiling and the Hispanic Experience" 2004 JCJ 607-616

Rowe Policing the Police

Rowe M Policing the Police: Challenges of Democracy and Accountability (Policy Press Bristol 2020) 
Sanders and Young "Police Powers"

Sanders A and Young R "Police Powers"in Newburn T (ed) Handbook of Policing $2^{\text {nd }}$ ed (Willan Portland 2008) 309-340

Tator et al Racial Profiling in Canada

Tator C et al (eds) Racial Profiling in Canada: Challenging the Myth of "a Few Bad Apples" (University of Toronto Press Toronto 2006)

UNODC Handbook on Police Accountability, Oversight and Integrity United Nations Office on Drugs and Crime Handbook on Police Accountability, Oversight and Integrity (United Nations New York 2011)

\section{Case law}

The People vs Tonfack Julienne and Kamdem Robert Judgment No 69/00 of 21 September 2000

\section{Legislation}

Law No 2005/007 of 27 July 2005 on the Criminal Procedure Code

Law No 2016/007 of 12 July 2016 on the Revised Penal Code

\section{Government publications}

MINJUST Report by the Ministry of Justice on the State of Human Rights in Cameroon 2005

MINJUST Report by the Ministry of Justice on Human Rights in Cameroon in 2006

MINJUST Report by the Ministry of Justice on Human Rights in Cameroon in 2007

MINJUST Report by the Ministry of Justice on Human Rights in Cameroon in 2008

MINJUST Report by the Ministry of Justice on Human Rights in Cameroon in 2009

MINJUST Report by the Ministry of Justice on Human Rights in Cameroon in 2010

MINJUST Report by the Ministry of Justice on Human Rights in Cameroon in 2011 
MINJUST Report by the Ministry of Justice on Human Rights in Cameroon in 2012

MINJUST Report by the Ministry of Justice on Human Rights in Cameroon in 2013

\section{International instruments}

African Charter on Human and Peoples' Rights (1981)

Basic Principles on the Use of Force and Firearms by Law Enforcement Officials (1990)

Convention Against Torture and Other Cruel, Inhuman or Degrading Treatment or Punishment (1985)

Draft Articles on Responsibility of States for Internationally Wrongful Acts (2001)

Guidelines for the Effective Implementation of the Code of Conduct for Law Enforcement Officials (1989)

International Code of Conduct for Public Officials (1996)

International Covenant on Civil and Political Rights (1966)

United Nations Code of Conduct for Law Enforcement Officials (1979)

Universal Declaration of Human Rights (1948)

\section{Internet sources}

Anon 2014 http://www.sirrobertmark.co.uk/portfolio/my-grandfather-marcus Anon 2014 Sir Robert Mark: From Constable to Commissioner. My Grandfather - Marcus http://www.sirrobertmark.co.uk/portfolio/mygrandfather-marcus/ accessed 30 January 2021

USAID 2020 https://www.usaid.gov/sites/default/files/documents/Police Accountability_Mechanisms_8.5.2020.pdf

United States Agency for International Development 2020 The Effectiveness of Police Accountability Mechanisms: What Works and the Way Ahead https://www.usaid.gov/sites/default/files/documents/Police_ Accountability_Mechanisms_8.5.2020.pdf accessed 30 January 2021 


\section{List of Abbreviations}

AHRLJ

AJCJS

AJIL

Can J Criminol Crim Justice

CAT

CPC

Cranbrook L Rev

Hum Rts Q

ICCPR

J Appl Secur Res

JCJ

MINJUST

UN

UNODC

USAID

Wis L Rev
African Human Rights Law Journal

African Journal of Criminology and Justice Studies

American Journal of International Law

Canadian Journal of Criminology and Criminal Justice

Convention against Torture and Other Cruel, Inhuman or Degrading Treatment or Punishment

Criminal Procedure Code

Cranbrook Law Review

Human Rights Quarterly

International Covenant on Civil and

Political Rights

Journal of Applied Security Research

Journal of Criminal Justice

Ministry of Justice

United Nations

United Nations Office on Drugs and

Crime

United States Agency for International

Development

Wisconsin Law Review 